\title{
Towards a missional hermeneutic informing missional ecclesiology and transformative theological education in Africa
}

\section{Pieter HJ Labuschagne ${ }^{1}$}

\begin{abstract}
Decolonisation and Africanisation are two sides of the same coin and cannot be engaged as separate, either-or options. Africanisation implies transformation by cultural incorporation and assimilation. In a positive way, one focusses on and seeks African attributes that can strengthen and contextualise the curriculum. The endproduct displays a rich African-ness. Decolonisation, implies separation, destruction and forceful removal. This targets the colonial curriculum and its eradication. The focus is on what we must dispose of, do away with, discard, and root out. The end-product is a curriculum that is purged from colonialism - without necessarily suggesting an African alternative.

A transformative missional hermeneutic is proposed that promotes mutualism between the theological curriculum, missiology, Scripture, and the African context. Gerhard von Rad's Traditionsgeschichte, Hans-Georg Gadamer's Wirkungsgeschichte and JNJ (Klippies) Kritzinger's Encounterology form the backbone of this missional hermeneutic, supported by contributions by African scholars.

Keywords: Decolonisation, Africanisation, transformative missional hermeneutics, missional ecclesiology, transformative theological education, Traditionsgeschichte, Wirkungsgeschichte, Encounterology, missio Dei, fusion of horisons and reversed colonialism.
\end{abstract}

\section{Introduction}

The Southern African Missiological Society (SAMS) invited papers for the January 2019 conference, dealing with the decolonisation and Africanisation of theological education, missiology and mission in the 21st century Africa. This represents a twofold goal: (i) to encourage missional churches to take part in transforming theological education and (ii) to allow transformative theological education to contribute to a missional ecclesiology that will bring about socioeconomic, political and religious transformation. This paper sets out to demonstrate that we will achieve neither of these without a fitting missional hermeneutic.

1 Dr Pieter Labuschagne is the Curriculum Coordinator at the South African Theological Seminary. He is also the pastor of Northway Baptist Church in Pretoria, Gauteng Province, South Africa. He can be contacted at pieter@sats.edu.za 
At the SAMS congress in Cape Town in 2017, the concepts of Africanisation and decolonisation were already embraced. This article handles these concepts as two sides of the same coin and not as separate, either-or options. The reason for this is that Africanisation and decolonisation inherently represent opposing methodologies: (i) Africanisation implies transformation by cultural incorporation and assimilation. In a positive way, one focusses on and seeks African attributes that can strengthen and contextualise the curriculum. The end-product displays a rich African-ness. (ii) Decolonisation, could point toward separation, destruction and forceful removal, brought on by the addition of the prefix $d e-.^{2}$ This targets the colonial curriculum and its eradication. The focus is on what we must dispose of, do away with, discard, and root out. The end-product is a curriculum that is purged from colonialism - without necessarily suggesting an African alternative.

When the two concepts above are applied in tandem, working together, to bring about a give-and-take result, a more balanced outcome is achieved.

We propose a transformative missional hermeneutic that promotes mutualism ${ }^{3}$ between the theological curriculum, missiology, Scripture, and the African context - based on contributions by Gerhard von Rad's Traditionsgeschichte (2001:xxxiii-xxxiv), Hans-Georg Gadamer's Wirkungsgeschichte (2013:310-317) and JNJ (Klippies) Kritzinger'sEncounterology (2008:764-790)

\section{A missional hermeneutic}

When considering missional hermeneutics, the missio Dei must take centre-stage. It is anchored in the Creator, who fashioned humans in His likeness, leading to an inherent God-desire in us. "This is not an imperialist claim that makes all human beings into 'anonymous Christians' against their will, but a humble faith affirmation that there is an ontological likeness among all human beings in their directedness towards God who created them, even if that is not (or not yet) an existential reality in their lives" (Kritzinger, 2008:764-790).

2 "a prefix occurring in loanwords from Latin (decide); also used to indicate privation, removal, and separation(dehumidify), negation (demerit; derange), descent (degrade; deduce), reversal (detract), intensity (decompound)". Viewed at https://www.dictionary.com/browse/de, last accessed on 15 November 2019.

“ De- is added to a verb in order to change the meaning of the verb to its opposite... De- is added to a noun in order to make it a verb referring to the removal of the thing described by the noun... removal of or from something specified... reversal of something... departure from". Viewed at https:// examples.yourdictionary.com/examples-of-symbiosis.html, last accessed on 15 November 2019.

3 "Symbiosis comes from two Greek words that mean "with" and "living". It describes a close relationship between two organisms from different species. It is sometimes, but not always, beneficial to both parties...There are several kinds of symbiosis to consider when looking for examples of symbiosis: Commensalism, Parasitism, Mutualism, Endosymbiosis and Ectosymbiosis". Viewed at https://www. collinsdictionary.com/dictionary/english/de_2l, last accessed on 15 November 2019. 
Mission takes place when we participate in the missio Dei, through spontaneous and intentional encounters with people in their contexts; this means that the gospel encounters people where they are. Van Aarde and Li-M (2017) emphasise that missional hermeneutic is both textual and contextual and that "...it arises from a specific cultural context and it addresses that cultural context through the application of Scripture to a specific cultural or missions context". Theology, ecclesiology or missiology that do not engage the context is inadequate and irrelevant.

The most challenging encounter probably occurs when human and divine horizons intersect; it is an encounter that demands a response $-a$ response with a bearing on the rest of a person's life. Aligning with God's horizon is a transformational experience, it is more than knowing about Him, it is more than abstract or interesting knowledge, it is life-changing. Jesus' mission brings reconciliation between man and God, ${ }^{4}$ it transforms humans, ${ }^{5}$ it gives eternal life, ${ }^{6}$ it is not a matter of mere words but of action, ${ }^{7}$ and it establishes a relationship between God and man. The separation that occurred in the garden ${ }^{8}$ is reversed. An instantaneous and ongoing fusion of horizons is established - a fusion of the highest order - between the human and the Divine. The person becomes a citizen of two worlds - he/she belongs to both but is also a stranger to both: in this world, but not of this world; ${ }^{9}$ a citizen of heaven, ${ }^{10}$ and yet awaiting the fullness of that salvation to be revealed. ${ }^{11}$

Encountering other horizons always disturbs the comfort of the status quo. We are questioned and we ask questions; we are challenged; conflicts arise; emotions are stirred; foundations are shaken; there is disillusionment; opportunities arise for our horizons to grow (or to remain the same - if we are not prepared to do self-reflection). From the first pages of the Bible, we encounter God as a questioning God. He called out to Adam and asked where he was, He asked Cain where his brother Abel was. God knew where they were, but He afforded them an opportunity to respond - to take responsibility and to be accountable. The questions were opportunities for growth in the fusion with God's horizon.

4 Rom 5:10-11; 2 Cor 5:18-20; Eph 2:14-17; Col 1:19-23.

5 Rom 12:2; 2 Cor 3:18; 5:17; Gal 2:20; 5:19-26; Eph 4:22-24; Col 3:10; Tit 3:5.

$6 \quad$ Mat 7:13-14; 25:46; John 1:12; 3:16; 3:36; 4:14; 5:24, 39; 6:40, 47, 50-71; 10:10, 27-28; 11:25-26; 14:6; 17:3; Acts 4:12; Rom 5:21; 6:22-23; 10:13; Gal 6:8; 1 Tim 1:16; 6:12; 1 John 5:11-13; 5:20.

Mat 7:21-27; Luke 6:46-47; John 14:15; Jas 1:21-25.

8 Gen 3.

9 John 15:19, 17:14-16.

10 Luke 22:29-30; Ephesians 2:19; Philippians 3:20; Hebrews 13:14; 1 Peter 1:4; Revelation 21:22, 22:3-5.

11 John 12:48; Acts 3:21; Ephesians 1:13-14; Philippians 1:6; 1 Timothy 6:14-15; 1 Peter 1:5, 13; 1 John 3:2; Hebrews 9:28. 
The questioning God also accepts being questioned. One of the best-known examples is Job, who refused to accept the neatly packaged "right-answer-theologies" of his friends. He challenges and questions God about his suffering. Finally, God responds and silences him - with a bombardment of questions! Jesus, who grew up in a questioning culture, used questions to draw a response from His listeners. He desired a personal response to His challenges; in fact, He still desires that today from each of His followers (Kritzinger 2002:144-145). Jesus' use of questions is crucial for missiological praxis.

The challenge of adopting a questioning paradigm is that you must accept being questioned, in return; you cannot anticipate or control what people will ask; their questions might not fit your predetermined theological convictions. As much as we desire a response to our questions, we need to respond when being questioned even if our answer is simply an internal reflection.

Let us pause for a moment to reflect on the supremacy of either the text or the context in the relationship between theology and mission. Some presuppose that theology deals with the text and its interpretation and mission deals with practical real-life situations. A balanced hermeneutic recognises that Scripture and context are interdependent. Theology that claims to be an objective examination of a text under a microscope, and then passing on those truths - without taking the context into consideration - implies one-way communication, which is of little value to the challenges people face today.

"Missional exegesis gives primacy to both the text and the context. Exegesis is done of the text and the culture. It involves biblical and cultural exegesis, an exegesis of the culture, history, motivations, and worldview of a particular cultural group of people" (Van Aarde \& Li-M, 2017). This dual dependence between theology and ecclesiology and the context people find themselves in, is not the complete picture. There are other dimensions involved: (i) someone needs to facilitate the process (Vanhoozer, 2006:94), and (ii) the whole activity is a spiritual activity, where we need to examine the Scriptures.

Context analysis is essential for missiology. In Mark 8:29 Jesus asked His disciples: "Who do you think I am?' Note, however, that in the previous verse He already asked them another question: "Who do people say I am?" (Mark 8:27). It was not only the disciples' personal opinions that mattered to Jesus - he wanted them to be aware of the context they lived in; they had to understand people around them. "With these two probing questions, Jesus has set an agenda for theological reflection, in which thorough context analysis is integral to theology" (Kritzinger, 2002:162).

When God sent His Son to the earth He lived in a real context with real people. He did not teach abstract, universal truths devoid of context. Through meaningful encounters with people, He challenges them with Kingdom principles using exam- 
ples from their context. Today missiologists, Christians and the church, should seek similar encounters with people around them. Kritzinger rightly says: "The nature of God's engagement with the world shapes the performance of Christian mission in fundamental ways" (Kritzinger, 2015:9).

Jesus transformed lives towards the reign of God (Kritzinger, 2013:3). Our encounters with others should have the same goal. No missiology, ecclesiology or theology should happen in a vacuum. Professor Johan Heyns encouraged students to read their Bibles side-by-side with the newspaper when preparing their sermons ${ }^{12}$. With this statement, he was advocating for theology and context to enter into dialogue. This reminds us of Kosuke Koyama's (1974:91) words: “...a Christian witness needs to do two kinds of exegesis: "exegesis of the Word of God, and exegesis of the life and culture of people among whom he lives and works".

Roots and wings is a fitting metaphor to illustrate the interplay between faith and culture (Kritzinger, 2008:145). When we overemphasise our traditions and our beliefs (our roots), we can develop tunnel-vision where we avoid or even reject the views of others; we do not spread our wings out of fear of contamination by the other. Surrounding oneself with likeminded people - building theological ivory towers - can lead to stagnation, conservatism or even fundamentalism. It can lead to judgmentalism, where the other is no more than an object or target of my persuasions (Kritzinger, 2008:4-5). Like with all extremes, overemphasising our wings can again lead to rudderless liberalism, where we are no longer trusted in Christian communities (Kritzinger, 2002:146).

One needs a balance between roots and wings: a willingness to explore and to be challenged by others who do not think in the same way you do. When we spread out wings and encounter contexts and viewpoints that challenge our theology or where our theology even falls short, we are forced to return to the drawing board and reflect on how the interaction with this context can enhance our theology.

\subsection{Von Rad's Traditionsgeschichte}

Gerhard von Rad valued the final text as the starting point and the end point of Old Testament Scholarship. Though he emphasised the importance of the final form of the text, he was also interested in how the text developed. This led him to the discovery of the Credo in Deuteronomy 26:5-9, which he identified as the basic confession of faith of God's people (Von Rad, 2001:xiv-xxv,122,136,296; Deuteronomy 26:59). In searching for the theological maximum, he discovered the historical minimum: the Credo. From this nucleus, he traced the development of Israel's traditions

12 This statement was made in 1990 during a first-year systematic theology lecture at the University of Pretoria. 
to the final form of the text. This not only helped him to understand the historical development of the text but also to grasp Israel's theological self-understanding. For von Rad this was the starting point of his theology and the basis for his Traditionsgeschichte (Lohfink, 1994:266).

He studied how the Credo was interpreted and applied to different historical contexts. Significant time passed between the first biblical record of the Credo and the last. Where interpreters often see this historical gap as an awful abyss, Von Rad was conscious of the wealth of historical tradition contained in the gulf that separated people and events in time; he used this to understand the Credo better. Instead of bridging the gap, or bypassing the gap, he highlighted its value. What seems to be a dividing gap, is in fact what binds us together across time and history.

According to Von Rad (2001:xvi), the Credo was open-ended, which enabled people to apply it afresh in every situation. One example of this is that Sinai, which forms the centre of the Pentateuch version in Deuteronomy, does not feature in some of the other versions of the Credo - except in the exilic and later ones (Nehemiah 9; Koopmans, 2009:322-323,443; Boda, 2012:22-23). Von Rad points out that each new generation understood God's promise to them within their own context. Their unique application of the Credo to their own context must not be seen as an alteration, but rather as a confirmation of its importance for them. They understood that God was with them just as He has been with their forefathers. Just as God worked then, He was working now. Kritzinger has the same in mind when he says: "The life of a Christian community should, therefore, be a faithful and impactful performance of the Christian message in a particular context" (Kritzinger, 2015:3).

Israel always asked questions of themselves and of God in their yearning for self-understanding; they reflected on their place and their role in history; how to understand themselves as Israel in every context. This process was balanced on a knife-edge between the known and the unfamiliar: something remained the same in their identification as God's people (holding on to their roots), but it had to be made relevant in every historical context (spreading their wings). "In a certain sense, every generation had first to become Israel" (Von Rad, 2001:119).

The value of the Credo in its various forms is that it preserves Israel's confession for their descendants ${ }^{13}$, it emphasises that the Land belongs to Jahwe and to no-one else $^{14}$, and that the God of the Credo is distinct from the gods across the river ${ }^{15}$. The Credo offered security and protection from anything that threatened their faith, it was their confession of how they experienced Jahwe and the world, and it was the proclamation of Jahwe's relationship with His people throughout history. That is why it was

\footnotetext{
13 Deut 6: 20-24.

14 Deut 26: 5-9.

15 Jos 24:1-13.
} 
so important for every generation to understand and confess the Credo in their own context. Von Rad called this revelation-as-testimony (Von Rad, 2001:xv).

Understanding for yourself is what gives humans hope and security; we are interpreting beings and we cannot understand independently of ourselves. Understanding is fundamental to our existence; it is a continuous process that we are involved in. The Old Testament scholar, who studies the historical text, also forms part of the broader historical reality; he studies how the infinite God broke into our finite world and how man describes God from his limited, historical perspective. What the scholar studies is God's activity in the world (and man's interpretation of it), against the backdrop of his own thrownness in this historical world. It draws him into the cycle of interpretation and re-interpretation that has been ongoing since the creation of mankind.

Von Rad's study of the credo, that is repeated through the Old Testament with variations (Von Rad, 2001:xxiii, 135; Seitz, 2007:22-23, 123-125), corresponds with Gadamer's Wirkungsgeschichte (2013:310-317) that all hermeneutic activity takes place within a concrete historical context (Boda, 2012:22-23; Boda \& Evans, 2017:9-26; Koopmans, 2009:322-323, 443).

\subsection{Gadamer's Wirkunsgeschichte}

Gadamer questions whether the distance that lies between the ancient text and the modern interpreter is an awful abyss, that cannot be traversed. His reply is that it is not an abyss to be feared, but that must rather be approached with expectation: it is filled with historical interpretations that are essential for our own understanding. It serves as a bridge between the text and the interpreter, which are both historical entities. Every historical interpretation is something that we can build on, and it is in the sum-total of these interpretations that the present is anchored. This continuous process of historical understanding and interpretation is what Gadamer calls Wirkungsgeschichte.

Human existence is historically determined: we understand and interpret in historical terms, and we play an active role in creating history but is in turn formed by history. This history-bound reality is the only reality that we know (Grondin, 1994:113). It is not a voluntary choice to engage in historical interpretation; it is how the human psyche is wired; we naturally form part of this dynamic, historical process of understanding (Weinsheimer, 1985:176). History is the foundation for our existence, but also the limit of our existence. Gadamer's contribution is not a new hermeneutical principle, but rather a rediscovery of the inherent ability of human beings to understand historically. Gadamer's hermeneutic contribution is not so much a methodology for understanding; it is rather an explanation of how Verstehen works (Weinsheimer, 1985:164). 
To understand historically entails a fusion between our horizon and ones from the past. Gadamer's reference to the fusion of different horizons does not mean that there are closed horizons that exist in isolation from one another; engaging a horizon from the past is not entering completely unknown territory. Every horizon is historically determined and therefore there is one broad horizon that we all form part of: that of history itself (Gadamer, 2013:315). The fusion of horizons is not the creation of a new horizon; it is rather a discovery of the broader historical horizon that all humanity belongs to.

Gadamer states that no horizon is ever closed and inaccessible. Horizons from the past are always in motion (Risser, 1995:80) and cannot be pinned down to one absolute point of view. In the fusion of horizons, the interpreter never leaves his own horizon to enter another, unknown one. Both horizons are anchored in one broad, historical reality, which continues to exist throughout history (Gadamer, 2013:303). It is impossible for any human to transfer himself or herself to another horizon - to understand the writer better than bimself - like Schleiermacher suggested (Gadamer, 2013:198). It is the fusion of two horizons (that continue to exist) that makes understanding possible (Vedder, 1997:129). We should not ignore or try to annul the tension that lies between horizons; we should rather work towards a historical horizon that looks different to the present one.

Gadamer highlights the role that prejudice or pre-understanding plays in the fusion of horizons. Prejudice can be defined as "judgements that are rendered before all the elements that determine a situation have been finally examined" (Gadamer, 2013:283). When we are conscious of our prejudice and bring it into play in the process of understanding, it enables us to identify things that we would not normally discern; it determines what we understand; it gives us access to other horizons. At first, it is very difficult to discern one's prejudice because it is finely woven into the fabric of our being, behaviour and beliefs. Hermeneutics requires us to become aware of our prejudice. Note that the prejudices that have the strongest influence on our lives are oftentimes the ones that we are the least aware of or the ones whose existence we deny (Gadamer, 2013:298). Gadamer mentions two dangerous viewpoints when dealing with prejudice:

1. The first rejects the existence of prejudice or argues that if prejudice does exist, we can remain neutral and keep our distance from it. This implies that one can push prejudice aside and engage with your study topic objectively. From this neutral position, we can then use the method of our choice to interpret our study topic. This approach assumes a self-emptying of prejudice. Gadamer points out, however, that this claim to objectivity, apart from prejudice, is prejudice in itself (Weinsheimer, 1985:170).

2. The second position makes no distinction between $u$ seful and harmful prejudice. The danger of this view is that harmful prejudice can direct and domi- 
nate the process of understanding; one can even intentionally choose harmful prejudices to direct the process or to manipulate the outcome in your favour. Gadamer urges us to deal responsibly with prejudice. He is not arguing for or against prejudice; he simply points out that we cannot understand without being influenced by our prejudice; it is how humans understand (Weinsheimer, 1985:175). When we recognise that we have prejudice and what role it plays in understanding, we can make corrections to harmful prejudices that are not conducive to understanding. Similarly, useful prejudice can enhance our understanding (Bernstein, 1989:128). Even though prejudice already exists before we start with the process of understanding, what we understand also alters our prejudice. This is the interactive process of understanding that we seek.

Context does not only influence our ability to understand - it shapes our understanding. It is the lens through which we come to understanding. Gadamer (2013:x-xxiv) points out how prejudice (see also Gadamer, Malpas, Arnswald \& Kertscher, 2002:315316) and pre-understanding (Gadamer \& Palmer, 2007:371) are essential building blocks for understanding. The self plays an important role in this process. Honest selfexamination is the mark of maturity and a prerequisite for meaningful encounters with others. Vanhoozer (2006:94) says, "Interpreters are never disembodied minds but embodied persons, persons who are male or female, persons who inhabit a particular place in space and time and so are susceptible to historical and cultural conditioning". Kritzinger (2008:7) applies this to missiology, "Personal bias and prejudice play such a large role in interfaith relations that they need to be declared and examined if a mature encounter is to take shape". We cannot understand in isolation of these influences. "The real meaning of a text, as it speaks to the interpreter, does not depend on the contingencies of the author and his original audience. It certainly is not identical with them, for it is always co-determined also by the historical situation of the interpreter and hence by the totality of the objective course of history" (Gadamer, 2013:307).

\subsection{Kritzinger's Encounterology}

Mission implies movement - going. There is movement in the missio Dei; there is movement from Christ's followers to those who are enemies and strangers of the cross ${ }^{16}$ there is movement from spiritual infancy to adulthood. ${ }^{17}$ The essence of missional ecclesiology is reaching out and making God known. The urgency of this movement and sentness can lead to an exaggerated focus on the lost. Everything related to the lost (who are seen as objects of our mission) is interpreted as corrupt and evil: from their culture and customs to their worldview, beliefs and reasoning.

${ }^{16}$ Colossians 1:21

171 Corinthians 2:1-3; Hebrews 5:12. 
The urgency of being sent with the good news can lead to the conviction that it would be best for the lost to be converted wholly to our beliefs and truths.

It is in opposing such an approach that encounterology, described by Kritzinger (2008:764-790), is so important. It is an essential prerequisite for missional ecclesiology and transformative theological education. We have random, spontaneous encounters with people on a daily basis but encounterology, as mission engagement, requires intentional encounters. "Proper planning and the longtime commitment of dedicated agents" (Banda \& Saayman, 2015:139) are needed. These encounters need to be reciprocal, where equal partners can converse. Encounterology directly opposes the view of missionaries with superior, colonial attitudes of a higher order, who instruct those of a lower order. "Too often we create the impression that Christians are the only actors on the stage, by describing only the praxis of the change agents who "go out" or "reach out" to bring about change" (Kritzinger, 2011:14).

In reflecting on mission, the church mostly focuses on the achievements of their missionaries, and the difference that they are making in pagan communities; and rightly, the church rejoices in the victory of light over darkness. Encounterology corrects this one-sided focus and points out that a mature encounter cannot take place where an interlocutor thinks he/she alone knows something that must be taught to another - who is ignorant. Instead of treating our interlocuters as objects, they need to become co-subjects in the conversation. As much as we have something to give, our interlocuters should have the freedom to either receive or reject it; in return, we need to allow them to offer something to us - irrespective of the fact that we receive it or reject it. "Mission "objects" are in fact subjects, active agents, deciding on the basis of their interaction with us whether (or to what extent) they wish to accept what we have presented to them" (Kritzinger, 2011:14). Earlier in my life, like many others, I resisted this approach out of fear that engagement in a reciprocal encounter will lead to compromise.

The danger of the traditional view that others are objects of our mission, who should be examined and described from a distance, is that it can easily become a form of "othering" (Kritzinger, 2008:2), which hinders reciprocal encounters. When we describe the other, without properly encountering them, they simply remain "an object of either interest, curiosity, sympathy, admiration, or conversation” (Kritzinger, 2008:2). For example, in reflecting on Piet Meiring's book Suid-Afrika: land van baie godsdienste (1996), Kritzinger comments on how Meiring writes about each religion, giving the correct information about that religion, and then concluding each chapter with guidelines for meaningful engagement with followers of those religions. Kritzinger points out that this seems methodically like an afterthought. "The theological method underlying it is that good theory leads to good practice" (2008:2). Make no mistake - information about the other is important; either a lack of information or wrong stereotypical infor- 
mation can be very harmful. It is not the knowledge about other traditions that is the problem here, but the methodology employed to attain that knowledge.

Our starting point should be encountering others and allowing them to speak for themselves, instead of starting with what we already know about them. Such encounters do not take place in a void; they take place in a historical context and all the interlocuters carry their own horizons into the encounter. Gadamer points out that we all have some form of pre-understanding (even if it might prove later to be erroneous). This does not negate the necessity to approach the encounter with a teachable mindset; all participants must be aware of their own prejudice and pre-understanding, as they discover more about the other. Ignoring your prejudice and pre-understanding is the worst form of ignorance. It is true that "one cannot change what one dare not confront" (Banda \& Saayman, 2015:141).

The norm in theology is to start with Scripture; to discover universal principles and truths that are then applied to particular contexts. ${ }^{18}$ This is a typical explicatio-applicatio approach: one needs to understand before you can communicate; correct understanding will automatically lead to the correct application. In my own ministry some inter-personal relationships suffered because I simply forced down what I saw as absolute Scriptural truth onto others. However noble the motive, this approach does more harm to contextual theology and contextual encounters than good. Therefore Kritzinger (2008:3) calls for a " ... more complex and inclusive theological method that brings into focus all the factors that shape religious identity and interreligious encounters."

"Mission as praxis is about concrete transformation; it is specifically about transformative encounters: among people, and between the living God and people, leading to people being called, sent, healed, and empowered...God's mission, the arriving of the reign of God, is about transformative encounters" (Kritzinger, 2011:13). If we are serious about transformative theological education, we will need a new approach for doing theology. This approach should encourage interactive encounters between theology and praxis, between ourselves and the other; between what we believe and who we are - leading to a discovery of the other and of ourselves. Transformative theological education can only take place in a milieu of encountering people and communities (Kritzinger, 2008:4,16).

Over the last few decades UNISA scholars to the likes of David Bosch, Inus Daneel, Willem Saayman, Bongani Mazibuko, and Johannes N.J. Kritzinger (Maluleke, 2009:9) developed a missiological praxis matrix, built on a strong hermeneutical foundation. This illustrates how hermeneutical principles like Traditionsgeschichte, Wirkungsgeschichte and Encounterology can be applied in missiological practice. The matrix

18 In my own studies at the University of Pretoria (1990-1995) we were taught a ten-step model of exegesis, where the last step was application. 
facilitates understanding of the self and the other along the lines of the following seven dimensions: spirituality, agency, contextual understanding, ecclesial scrutiny, interpreting the tradition, discernment for action and reflexivity. What Kritzinger calls encounterology is the backbone of this missional hermeneutic. We don't merely want to understand the facts about ourselves and the other; we want to establish a relational encounter.

The praxis above challenges one to act reflectively and to reflect on one's actions. It is collective, transformative, action that integrates thinking and acting, praying and working (Kritzinger, 2002:149). "It is the constant interaction between theory and practice, acting and thinking, praying and working. It is also:

a. Transformative: i.e. thinking-and-acting for change

b. Communal thinking-and-acting: i.e. not an individual matter"

(Kritzinger 2011:11).

Transformation is achieved through praxis; praxis implies a method which leads to action, but that also emerges from action. In the praxis of encounterology, the distance and the strangeness between people are removed and connection is established between them. Kritzinger points out that Jesus's question "Who do you say I am?" should also be heard as "What do you do...if this is who you say I am?" What makes this question missiologically relevant is the fact that it can be answered adequately only in words and deeds (Kritzinger, 2002:147).

Kritzinger's praxis matrix levels the playing field. The top-down imperialist approach of imposing one's convictions on others is replaced by a process of discovering the self, the other and our togetherness. It emphasises being with others, rather than doing things for them (Wells, 2015:30-31). It is a collective approach, demanding humility from all participants, with no predetermined agenda. "The praxis matrix is designed for groups of people who covenant together to make a difference to their society" (Kritzinger, 2002:150), held together by the mutual conviction of the centrality of the missio Dei. The praxis matrix is not a "superficial recipe or a set of multiple-choice alternatives" (Kritzinger, 2002:147). It should be seen as a method that leads to action and that is at the same time defined by action. The flexibility and integrative nature of the praxis matrix leads to a constant interplay between the different dimensions. A commitment to engage with all the dimensions of the praxis matrix safeguards participants from hidden agendas, where one aspect could be elevated above (or at the cost of) others.

\section{Africanisation of theology and missional ecclesiology}

Hermeneutics calls for intentional encounters, where a fusion of horizons can take place; it is a necessary requirement for human interaction and mutual understanding. One way in which apartheid estranged cultures in South Africa was through separate education systems and separate geographical areas of habitation. Separate but equal 
sounded like an acceptable model for a multicultural society, but in reality, whites enjoyed privileges that others did not have. This separation and estrangedness between people made a proper hermeneutical understanding between cultures impossible.

During apartheid, residential separation isolated people from different backgrounds from one another; many (especially white) Christians had very few (if any) encounters with people from other religions and cultures. In a post-apartheid South Africa, people are still struggling. The results of years of separation and avoiding the other runs deeper than geographical residential separation. Even though more diverse people now come into contact with one another, meaningful encounters are still something to be desired. False perceptions and propaganda over decades sowed the seeds of suspicion and distrust. What is unfortunate is that racial, cultural, gender and class identities have become closely linked to religious identity (Kritzinger, 2008:9).

In the height of apartheid, our country witnessed Christian denominations that justified the evils of apartheid from Scripture. Church members whose theology was shaped in such a milieu, find it hard to move on: it presents them with a faith-crisis. They are disillusioned and experience a crisis in their theological convictions. The same is true of those who were disadvantaged through the apartheid system. Their theological canvas was painted as the oppressed - struggling for liberation. This is carried into the post-apartheid era with us.

To deracialise these relations between cultures, theology needs to move towards an intercultural curriculum. Kritzinger mentions multilingualism as one way of achieving this, because theology became more and more English - without taking into account people's home and ministry languages (Kritzinger, 2013a). If, however, multilingualism reaches only as far as translating non-African theology from English to the vernacular, it is nothing more than a sugar coating. It is only when the heart and mind of the language engage others in meaningful encounters, and theology flows from it, that we can speak of the emergence of an Africanised theology.

We referred earlier to theological approaches, which extract universal principles and truths from an objective study of Scripture (a typical explicatio-applicatio approach) and then communicate it to others irrespective of their contexts. This is how colonial theology was established in Africa: those with the Gospel had the answers and Africans had to learn it. It is therefore fitting that the SAMS congress in Cape Town in 2017 embraced the concepts of Africanisation and decolonisation of theological education. It is, nevertheless, critically important that the right missional hermeneutic is employed to bring this about.

\section{Encountering Hermeneutics}

Apartheid affected all South Africans; it is part of the world we know - no matter on which side of the divide we find ourselves. What we need is a honest examination 
of who we are collectively and individually; we must ask Jesus questions and allow Him to ask us questions; we must seek deliberate encounters with Scripture, different contexts, and people who are different from us; we must give and be willing to process what we receive - with the sole purpose of drawing closer to God and to one another in a way that honours Him and that gives birth to a truly indigenous missional ecclesiology and transformative African theology.

We need new voices - non-colonial, African voices - to make us aware of our existing biases, which influence our view of other's cultures. "It will also reveal to practitioners of theologies how myoptic and insensitive they often are in the way they perceive their own religious traditions - and those of their neighbours" (Kritzinger, 2008:2). A need to decolonise theology (and eradicate its evils) is understandable, but when conducted without the right encounters it could be as harmful to theology as colonialism itself. What qualifies a curriculum as colonial is both the content and how it is introduced. The colonial way of introducing things is from the top-down - instead of from a viewpoint of participation. Colonialists failed to spread their wings and to accept the challenge of being transformed by their encounters with Africans. Africa would err if so-called decolonising transformation is forced onto the curriculum in a similar fashion.

\section{Conclusion}

In this paper we pointed out the inherent methodological difference between Africanisation and decolonisation and stressed the importance of them operating in tandem - not as either-or activities. Colonial curricula need to be addressed, but if its eradication is our only agenda, without offering a valid African alternative, we have failed. If decolonisation elevates one party over the other and only focuses on rooting out the colonial curriculum, encounterology suffers. If $d e$-colonisation is the driving force behind the transformation of theology, we run the risk of "reacting against" colonial elements in a way that is surprisingly similar to the colonial approach that we are trying to eradicate. It is then just another system that is forced down from the top without a fusion of horizons: a reversed colonialism.

We would do much better to adopt a positive missional hermeneutic; one where colonial theology is engaged as an interlocutor. Intentional encounters should take place; encounters of listening and sharing; of interaction and participation. If these encounters result in the discovery and formulation of who the role players are, and what their theologies are, an Africanised curriculum will emerge.

Kritzinger (2002:146) echoes this when he points to the value of roots and wings in the decolonisation of theological education.

If I should say: "I am in the first place African and only secondly Christian", there is the danger that my rootedness in the culture and language of my own community 
could become so dominant that I close myself off from others and become a narrow and ethnocentric believer. Conversely, if I say: "I am firstly Christian and only secondly African", I could slip into a superficial internationalism, without organic roots in my community. The more deeply I am rooted in a community of people, however, hybridised its language and culture may be, the more I am empowered to become a sensitive intercultural Christian. ${ }^{19}$

We are proposing a missional hermeneutic that reaches further than an encounter between two partners. A hermeneutic that underlies the Africanisation of theology involves not only Africans but also the existing (colonial) theology curriculum, Scripture, context and missiological facilitators. If these role-players deal with their respective prejudices and allow for a kind of encounterology like what Kritzinger proposes in his praxis matrix, an authentic Africanised theology and ecclesiology will emerge.

\section{References}

Bernstein, R.J. 2011. Beyond Objectivism and Relativism: Science, Hermeneutics, and Praxis. University of Pennsylvania Press.

Boda, M.J. 2012. Praying the Tradition: The Origin and the Use of Tradition in Nehemiah 9. Berlyn: De Gruyter.

Boda, M.J., \& Evans, C. 2017. The Heartbeat of Old Testament Theology. Ada, MI: Baker Academic.

Gadamer, H.G. 2013. Truth and Method. London: Bloomsbury Academic.

Gadamer, H.G., Weinsheimer, J., \& Marshall, D.G. 2013. Truth and Method. The Bloomsbury Revelations Series. London: Bloomsbury.

Gadamer, H.G., Malpas, J., Arnswald, U., \& Kertscher, J. 2002. Gadamer's Century: Essays in Honor of Hans-Georg Gadamer. Cambridge, MA: MIT Press.

Gadamer, H.G., \& Palmer, R.E. 2007. The Gadamer Reader: A Bouquet of the Later Writings. Evanston, IL: Northwestern University Press.

Grondin, J. 1994. Introduction to Philosophical Hermeneutics. London: Yale University Press.

Koopmans, W.T. 2009. Joshua 24 as Poetic Narrative. London: T\&T Clark.

Kritzinger, J.N.J. 2002. A Question of Mission - A Mission of Questions. Missionalia, 30(1), 144-173.

—. 2008. Faith to Faith - Missiology as Encounterology. Verbum et Ecclesia, 29(3), 764790.

-. 2011. "Mission as..." must we choose? A Dialogue with Bosch, Bevans \& Schroeder and Schreiter in the South African Context. Missionalia, 39(1-2), 32-59.

—. 2013a. Opening up Intercultural Learning Space: The Potential Contribution of a Multilingual Theological Dictionary. Unisa dictionary team presented this paper at a

${ }^{19}$ Kritzinger 2002:146. 
conference of ATISCA (Association of Theological Institutions of Southern and Central Africa) in Lusaka, Zambia in July 2013.

—. 2013b. Mission in Prophetic Dialogue. Missiology, 41(1), 35-49.

- . 2015. Mission Theology and The Nature of God. An unpublished paper delivered in honour of Chuck van Engen, Unisa.

Lohfink, L.M. 1994. Theology of the Pentateuch: Themes of the Priestly Narrative and Deuteronomy. Minneapolis: Fortress.

Maluleke, T. 2009. Special Appreciation and Acknowledgements. Missionalia: South African Journal of Mission Studies, 33(3), 9.

Meiring, P. 1996. Suid-Afrika, Land van Baie Godsdienste. Pretoria: Kagiso.

Risser, J. 1995. Hermeneutics and the Voice of the Other. Re-reading Gadamer's Philosophical Hermeneutics. Albany: State University of New York Press.

Seitz, C.R. 2007. Prophecy and Hermeneutics: Toward a New Introduction to the Prophets. Grand Rapids, MI: Baker.

Van Aarde, T.M., \& Li-M, L. 2017. A Fruitful Missional Exegesis for a Missional Hermeneutic and Missiology, In die Skriflig, 51(2).

Vanhoozer, K.J. 2006. One Rule to Rule Them All?: Theological Method in an Era of World Christianity, in Ott, C. and Wetland, H.A. (eds.), Globalizing Theology: Belief and Practice in an Era of World Christianity, pp. 85-126, Grand Rapids: Baker Academic.

Vedder, B. 1997. Wandelen met Woorden: Een Weg van de Filosofische Hermeneutiek Naar de Hermeneutische Filosofie en Terug. Best: Damon.

Von Rad, G. 2001. Old Testament Theology, Volume 1: The Theology of Israel's Historical Traditions. Louisville, KY: Westminster/John Knox.

Weinsheimer, J.C. 1985. Gadamer's Hermeneutics: A Reading of Truth and Method. London: Yale University Press.

Wells, S. 2015. The Power of Being With: Jesus' Model for Ministry. The Christian Century. Available from: https://www.christiancentury.org/article/2015-06/power-being (Accessed on 18 November 2019). 